\title{
Publisher Correction to: Psychosomatic symptoms questionnaire (PSQ-39): a psychometric study among general population of Iranian adults
}

\author{
Zahra Heidari ${ }^{1,2}$, Awat Feizi ${ }^{1,2^{*}}$, Sara Rezaei ${ }^{1,3}$, Hamidreza Roohafza ${ }^{2}$ and Peyman Adibi ${ }^{4,5}$
}

Publisher Correction to: BMC Psychiatry 21, 269 (2021)

https://doi.org/10.1186/s12888-021-03278-z

Following the publication of the original article [1], the authors identified that the incorrect additional file 1 was published. The correct file has been published.

The original article [1] has been corrected.

The publisher apologizes to the authors and readers for the inconvenience.

\section{Supplementary Information}

The online version contains supplementary material available at https://doi. org/10.1186/s12888-021-03328-6.

Additional file 1. Psychosomatic Symptoms Questionnaire (PSQ-39)
Published online: 09 July 2021

\section{Reference}

1. Heidari, et al. Psychosomatic symptoms questionnaire (PSQ-39): a psychometric study among general population of Iranian adults. BMC Psychiatry. 2021;21:269. https://doi.org/10.1186/s12888-021-03278-z.

\begin{abstract}
Author details
'Department of Biostatistics and Epidemiology, School of Health, Isfahan University of Medical Sciences, P.O. Box 319, Hezar-Jerib Ave, Isfahan 8174673461, Iran. ${ }^{2}$ Cardiac Rehabilitation Research Center, Cardiovascular Research Institute, Isfahan University of Medical Sciences, Isfahan, Iran. ${ }^{3}$ Student Research Committee, School of Health, Isfahan University of Medical Sciences, Isfahan, Iran. ${ }^{4}$ Gastroenterology and Hepatology Research Center, Isfahan University of Medical Sciences, Isfahan, Iran. ${ }^{5}$ Department of Internal Medicine, School of Medicine, Isfahan University of Medical Sciences, Isfahan, Iran.
\end{abstract}

The original article can be found online at https://doi.org/10.1186/s12888021-03278-z

* Correspondence: awat_feiz@hlth.mui.ac.ir

'Department of Biostatistics and Epidemiology, School of Health, Isfahan University of Medical Sciences, P.O. Box 319, Hezar-Jerib Ave, Isfahan 8174673461, Iran

${ }^{2}$ Cardiac Rehabilitation Research Center, Cardiovascular Research Institute, Isfahan University of Medical Sciences, Isfahan, Iran

Full list of author information is available at the end of the article
Ready to submit your research? Choose BMC and benefit from:

- fast, convenient online submission

- thorough peer review by experienced researchers in your field

- rapid publication on acceptance

- support for research data, including large and complex data types

- gold Open Access which fosters wider collaboration and increased citations

- maximum visibility for your research: over 100M website views per year

At BMC, research is always in progress.

Learn more biomedcentral.com/submissions

C The Author(s). 2021 Open Access This article is licensed under a Creative Commons Attribution 4.0 International License, which permits use, sharing, adaptation, distribution and reproduction in any medium or format, as long as you give appropriate credit to the original author(s) and the source, provide a link to the Creative Commons licence, and indicate if changes were made. The images or other third party material in this article are included in the article's Creative Commons licence, unless indicated otherwise in a credit line to the material. If material is not included in the article's Creative Commons licence and your intended use is not permitted by statutory regulation or exceeds the permitted use, you will need to obtain permission directly from the copyright holder. To view a copy of this licence, visit http://creativecommons.org/licenses/by/4.0/. The Creative Commons Public Domain Dedication waiver (http://creativecommons.org/publicdomain/zero/1.0/) applies to the data made available in this article, unless otherwise stated in a credit line to the data. 